\title{
ЕВОЛЮЦІЯ БЛИЗНЮКОВОГО МІФУ \\ У ДАВНЬОСХІДНІЙ ТРАДИЦІЇ
}

У статті зосереджсено увагу на розвиткові $i$ трансформачіі близнюкового міфу в давньосхідному середовищі на прикладі давньої міфології присередземноморських культур (Давній Сгипет, Месопотамія, Палестина). Сюжет про братів-близнюків (життєвих антиподів) неодмінний складник давньосхідної літературної традиції, $i$ поруч iз космогонічними і антропогонічними міфами є архетиповим. Проаналізовано давньоєврейські варіанти близнюкового міфу, представлені в текстах Тори (П'ятикнижжя Мойсея), простежено еволюиію близнюкової метафори в старозавітних оповідях про Каїна та Авеля, Ісава $і$ Якова, Йосифа Прекрасного. Спостерігається засвоєння близнюкових сюжетів традицією Передання аврамістичних віровчень.

Ключові слова: Давній Схід, близнюковий міф, ТаНаХ, Тора, Каїн і Авель, Ісав і Яків, Йосиф Прекрасний.

Повсюдне поширення у давньосхідному, а пізніше в елліністичному світі близнюкового міфу вказує як на його давність, так і на необхідність його у певних аспектах народної філософії, коли без близнюкової метафори, без віддзеркалення чи протиставлення життєвих позицій і пріоритетів обійтися було неможливо. У різних культурах близнюки - такий же архетиповий образ як і світове дерево; обидва символи, як відзначає В. В. Іванов, навіть пов'язані між собою. У суспільствах, які вшановують близнюків, звичайними $\epsilon$ обряди, що сполучають їхній культ із символікою родючості $[6,175]$.

Уявлення про близнюків надзвичайно варіативні і суперечливі: навіть сам погляд на них не $\epsilon$ амбівалентним, хоча амбівалентність природних стихій $\mathrm{i}$ явищ (і богів, що їх втілюють) лежить в основі давньосхідної міфічної свідомості. 3 одного боку, народження близнюків часто вважалося наслідком порушення подружньої вірності (так було у Вавилоні, Сгипті, Абіссінії). 3 іншого боку, таке народження вважалося особливим знаком богів, їхньою милістю, багато з яких і самі були близнюками: кожен близнюк вже від народження і в силу народження - істота божественна, в усякому випадку істота надприродна [9].

Відомі численні міфи про близнюків, котрі часто є родоначальниками племені або культурними героями. Близнюкові міфи типологічно класифікують на міфи про близнюків-братів (суперників або - пізніше союзників), близнюків брата і сестру, близнюків-андрогінів та зооморфні близнюкові міфи [6, 174].

У міфах про братів-близнюків один із персонажів пов'язується з усім благим, корисним, чистим, інший - з усім злим, погано виконаним, нечистим (давньоєгипетські Осиріс і Сет, біблійні Каїн та Авель тощо). Саме цей тип 
міфу однозначно вибудовує критерії моральності у часи, коли міфічна свідомість витісняється релігійною чи філософською. В основі неприйняття близнюками один одного, відкритої ворожнечі, лежить міметична криза, або криза відмінностей (Р. Жірар) [20]. Міф однозначно акцентує на наслідках такої ворожнечі, коли моральні інтенції стають вчинками, які незворотно міняють початкову картину світу, роблять світ різнополюсним, привносячи в людську історію протистояння і війни.

Одним із перших сюжетів Тори (одразу після космогонічної оповіді і оповіді про гріхопадіння) є історія про братів-близнюків Каїна і Авеля (Бут. 4, 1-16). Якщо розглядати цей сюжет із точки зору міметичної кризи i ритуального вбивства (жертвоприношення), то його можна трактувати як «істинну жертву - неістинну жертву», враховуючи спонукальні мотиви суперництва різного роду жертви. Криза відмінностей пов'язана 3 комплексом первинних елементів «центрації» людської спільноти мімезисом, насиллям і жертвоприношенням. Специфіка жертви полягає в тому, що вона не залежить від волі людини, а санкціонується джерелом абсолютної духовності, тобто Богом. Цього не можна заслужити. Жертва стає джерелом постійного i зростаючого суперництва. Енергія конкуренції зосереджується на першоджерелі власника самої жертви - Богові. Енергія суперництва перенаправляється на свідомо обрану жертву. Якщо об'єкт (Бог) є недосяжним, гнів переноситься на об'єкт заміщення [19].

Перше вбивство людини людиною в аврамістичних релігіях братовбивство. Історія ТаНаХу про Каїна і Авеля стала алегорією, що розкриває природу людської сутності. Коротка (всього шістнадцять віршів) оповідь, таємнича і неоднозначна в кожній своїй деталі, починається 3 прабатьків - Адама і Сви, котрі, будучи вигнаними з Едему, народжують двох синів. Землероб Каїн і його молодший брат пастух Авель намагаються кожен у свій спосіб догодити Богові, проголошуючи подячні молитви i приносячи жертви. Перше ритуальне жертвоприношення, описане в Книзі Буття, - це оповідь про те, як кожен брат приносить жертву згідно зі своїм родом занять: Каїн звертається до Бога, пропонуючи йому в жертву частину свого врожаю, Авель приносить у жертву первородне ягня зі свого стада. Бог приймає дар Авеля, але не приймає жертви Каїна без всяких очевидних причин. Це перша з багатьох загадок міфу. Текст не містить відповіді, чому Бог надав перевагу одній жертві над іншою. Каїн сповнений люті і ревнощів до свого більш успішного брата і кидається на нього: «I коли вони були в полі, Каїн напав на Авеля, свого брата, й убив його» (Бут.4, 8) ${ }^{1}$. I ось ще одна загадка: якщо раніше нікого не вбивали, тим більше умисно, то звідки Каїн знав, як саме вбивати? Чи зрозумів він узагалі, що скоїв? «Тоді Господь сказав до Каїна: «Де Авель, брат твій?» Той відповів: «Не знаю. Хіба я сторож брата мого?» А Господь промовив: «Що ти вчинив? Ось голос крові

\footnotetext{
${ }^{1}$ Цитація біблійних текстів дається за перекладом під орудою I. Хоменка: Святе Письмо Старого та Нового Завіту - Рим: Verbo Divino, 1988.
} 
брата твого кличе до мене з землі. Тепер же проклятий ти від землі, що відкрила свої уста, щоб прийняти кров брата твого з твоєї руки» (Бут. 4, 9-11).

Тора однозначно демонструє, наскільки Бог розгнівався на Каїна за те, що той учинив жахливий злочин. Однак після смерті Авеля відбувається абсолютно дивний обмін між Каїном і Богом: Яхве засуджує Каїна не до смерті, а до вигнання, вбивця приречений блукати на самотині: «Проганяєш оце мене сьогодні 3 цієї землі, й від лиця твого мушу ховатись і тікати та волоцюгою маю бути на землі; і перший, хто мене зустріне, вб'є мене. Тоді Господь сказав до нього: «Якщо хтось уб’є Каїна, то зазнає помсти всемеро». Та й поклав Господь на Каїні знак, щоб не вбивав його той, хто зустріне його» (Бут. 4, 14-15). Обіцянка Яхве помітити Каїна знаком, щоб ніхто, 3 ким той зустрінеться, не зашкодив йому, $є$ черговою таїною: якщо 3 самого початку існують лише Адам і Сва, Каїн і Авель, яких людей Каїн боїться зустріти в пустелі? І що це за знак Каїна? Врешті Каїн дістався до землі Нод, що на схід від Едему, і так ніколи й не повернувся додому. Таємничі вірші, що породжують більше запитань, аніж відповідей, але очевидна етична думка давньоєврейського тексту звучить доволі ясно: так, ти сторож своєму братові.

Давні культи хоча i вшановують обох близнюків, народженим від божества вважається лише один, зазвичай той, що народжений другим, оскільки божество приєднує свою дитину до вже зачатої людської $[15,86]$. Старший брат Каїн з'явився на світ у результаті відпадіння першолюдей від Бога, а через це був нелюбимим сином, постійним нагадуванням для батьків про їхнє гріхопадіння. Мотив улюбленого молодшого (а не старшого) сина повториться і в інших близнюкових сюжетах ТаНаХу: про Ісмаїла і Ісаака (Авраам практично відречеться від свого первістка, народженого від Агари), про Ісава і Якова, про Йосифа і його братів. Відомі подібні сюжети і в паралельних до давньоєврейської літературах, наприклад, у давньоєгипетській («Казка про двох братів»), хоча пізніше, під впливом міфів про Осиріса і Сета близнюковий сюжет у Сгипті актуалізує молодшого брата у якості негативного персонажа, охопленого заздрістю i ревнощами до первородного права старшого [4]. Автор ТаНаХу однозначно наполягає, що фізичне первородство для Бога не є визначальним, він оцінює первородство духа. Крім того, символіка імен перших братів дає зрозуміти глибинний підтекст майбутнього конфлікту: ім’я Каїн походить від дієслова «набувати (в матеріальному сенсі)», а Авель - від дієслова «дихати» [17, 69]. Вибір Бога свідчить про пріоритет духовного життя вільних пастухів над матеріальною залежністю від землі хліборобів (пастухами пізніше будуть такі ключові фігури ТаНаХу як Мойсей і Давид). Конфлікт братів неминучий - людина, занурена в тілесне, земне, завжди буде намагатися усунути людину духовну, саме існування якої $є$ запереченням споживацької моралі. Та й 3 моменту гріхопадіння праця на землі вважалася прокляттям, виснажливою мукою «в поті лиця», тоді як діяльність пастуха сприяла спогляданню і молитві, проте в очах землероба виглядала майже ледарством.

Знак Каїна часто сприймається як знак прокляття, кари. Але його можна також інтерпретувати як знак милості Божої, гарантію захисту. Але навіщо 
Богові захищати Каїна, холоднокровного вбивцю? Давні раввіни, що досліджували ТаНаХ, висунули версію: якщо перед тим, як Каїн вбив Авеля, ніхто ніколи не помирав, і якщо Каїн не знав, що відбудеться, коли він вдарить брата камінцем, злочин не був насправді вбивством, але нещасним випадком. А в давніх судах юдеїв вбивство через необережність не каралося смертю [2; 3]. Інша знаменита зрада в Біблії відбудеться значно пізніше, і це буде вже євангельська історія про Ісуса Христа. Він, що проповідував братство і всепрощення, буде зраджений на смерть своїм учнем Юдою, і прийме цю смерть зі смиренням і ненасиллям. По суті моління «Отче, відпусти їм, не знають бо що роблять» (Лк. 23, 34) є євангельською молитвою відкуплення за Каїна, котрий, вбиваючи, не знав, що таке насправді вбивство чи смерть. Однак теологічна думка так і не розробила гіпотезу, що то був за знак Каїна, знак, яким Бог помітив першого вбивцю. Природа знака, очевидно, не стільки важлива, як те, що Бог не допустив помсти Каїнові 3 боку людей, дав йому можливість усвідомити скоєне і мати потенційне право на каяття або жити 3 ношею смертної провини. Згідно з Талмудом, Каїн і увесь його рід гинуть у водах потопу, так і не розкаявшись [3].

Існує більше десятка тлумачень цієї близнюкової оповіді, що виникли в юдейській, християнській і мусульманській традиціях. Кожна з них додає досить оригінальні й подекуди суперечливі деталі у спробі ув'язати таємниці й протиріччя цієї історії $[2 ; 3 ; 8 ; 10 ; 16 ; 17]$. Попри багатовікові міжусобиці, війни й кровопролиття, юдеї, християни й мусульмани сходяться в одному: вони сповідують віру в єдиного Бога і ідеї, що всі ми нащадки Адама й Єви, давніх єврейських племен і праотця Авраама. Головна, незмінна ідея Божої любові і всепрощення є фундаментальною і об'єднавчою силою, яка стоїть за великими світовими релігіями. Тим не менше кожна релігія проникає в сенс історії своїм способом, починаючи 3 причини конфлікту у тексті: чому принесене в жертву Каїном зерно було відкинуте, а пожертвувана Авелем кров була прийнята? В деяких коментарях до Корану Бог не просто приймає жертву Авеля, але робить це демонстративно [8]. Визнавши, що ТаНаХ не дає пояснень Божої прихильності, екзегети допускають, що рішення проблеми може полягати в зовсім іншому, несподіваному ракурсі. Головна ідея тексту не в тому, чому одна жертва була прийнята, а інша відкинута ідея в тому, що сам факт відкинутої жертви не повинен призвести до кровної ворожнечі і до вбивства. Екзегеза вбачає дидактичну спрямованість тексту в тому, що Яхве випробовує Каїна, щоб він зрозумів і визнав, що в його брата $\epsilon$ здібності і талант, яких він не має, щоб він зрозумів, що замість піддаватися ревнощам, він може мати користь із здібності брата догоджати Богові. Іншими словами, ніхто не може мати всього. I тому ми залежимо один від одного, є недосконалими частинами досконалого цілого. Замість того, коли Авель отримує винагороду від Бога, Каїн сповнюються обурення.

Інші юдейські та ісламські тлумачі $[5 ; 16 ; 18]$ пропонують причину, з якої Бог приймає жертву Авеля, а не Каїна. Серце Авеля - серце праведника, а Бог всезнаючий, Він знає наші серця. Але що такого міг зробити Каїн, що образив Бога? В обох традиціях пропонується різне пояснення незрозумілого 
фрагменту Книги Буття. Згідно 3 деякими юдейськими й ісламськими теологами причина конфлікту між двома чоловіками банальна - жінка: Каїн забажав жінки, яка призначалася Авелю [2; 16]. В цьому криється причина невдоволення Бога старшим братом. Тлумачі, опираючись на Передання, вважають, що у Каїна й Авеля була сестра, яку звали Аван. У Книзі Буття шлюби між братами і сестрами не вважалися інцестом, оскільки інших людей на землі просто не було. Тепер невдоволення Каїна здається трохи більше зрозумілим. Бог прихильний до Авеля і в шлюбі, i в жертві. Господь попереджає Каїна, що він повинен позбутися злих помислів, але той не зважає на його поради. Тому Каїн просить брата піти з ним в поле - у нього зріє жорстокий умисел. Із століття в століття ісламська традиція додає все більше деталей до цієї історії, яка підкреслює миролюбний норов Авеля [16]. Два чоловіки сперечаються, між ними виникає сварка, і Авель - прихильник ненасилля - у кращих традиціях багатьох поколінь подібних прибічників лягає на землю і каже: «Аллах, роби зі мною, що хочеш». Коли Каїн бачить це, він не може вбити його, як би не намагався. Тоді з'являється диявол і говорить із Каїном, і радить йому, як вчинити вбивство: підказує Каїнові вдарити брата каменем по голові, що той згодом і робить. Але що значить вбивство і смерть як прецедент у світі безсмертя? Ісламські екзегети припускають наскільки новою і шокуючою була така ситуація. Один із них описує, як зловтішний диявол вперше породжує у світі горе і біль. Коли диявол приходить до Єви, яка ще не знає, що ії молодший син загинув, він розповідає їй про це. «Твій молодший син не повернеться до тебе». «Про що ти говориш?» «Він помер, він вбитий». «Що значить помер, що значить вбитий?» I оскільки це початок всього, що стосується існування людини, диявол пояснює: «Він більше ніколи не говоритиме 3 тобою, він не повернеться, він не буде їсти, не буде сміятися, не буде дихати» [8; 16].

Біблійний міф і передання про Авеля і Каїна пов'язані з більш давніми близнюковими сюжетами давньосхідної традиції, зокрема 3 шумерською легендою про сватання до богині кохання Інанни бога землеробів Енкімду і бога скотарів Думузі. У цьому міфі Інанна обирає собі чоловіком саме покровителя пастухів, який намагається спровокувати сварку зі своїм суперником. Однак Енкімду не бажає ворожнечі і пропонує Думузі випасати череди на своїх пасовиськах, а той у свою чергу запрошує Енкімду на весілля. Шумерський міф, на відміну від біблійного, закінчується мирно, і не має етичного наповнення про заборону братовбивства (кровопролиття в широкому сенсі). Інші функції мають і герої: у шумерському міфі покірним норовом наділено землероба, а не пастуха, як у ТаНаХу. Однак в обох текстах очевидна перевага над працею землероба праці скотаря, як більш значимої для тогочасної свідомості, що пояснюється кочовим минулим близькосхідних племен, адже в середовищі кочівників саме худоба забезпечувала життя і добробут (м'ясо, молоко, одяг, тяглова сила тощо) [12].

Історія Каїна і Авеля - перший у монотеїстичній традиції випадок смерті, вбивства, з якого, згідно з ТаНаХом, горе множиться в людській історії. Сльози, роздирання одежі, скрегіт зубів і кровопролиття - лише 
відображення того, як людина вдруге була позбавлена Божої благодаті, вбивши брата. I весь текст ТаНаХу наповнений історіями, які перекликаються 3 найжорстокішими моментами оповіді про Каїна і Авеля. Брати повстають один проти одного через сім'ю, кров, спадок, ревнощі. Але 3 часом відбувається щось глибоко нове: озлоблені брати навчаються прощати. I свідченням цього $є$ інший близнюковий сюжет Тори - оповідь про братів Ісава і Якова.

Долі Ісава і Якова переплетені, але разюче відмінні, їхнє суперництво - це piзні (а вірніше, протилежні) стратегії життя в суспільстві i, таким чином, різні можливості організації спільноти, які, разом узяті, окреслюють напрямки подальшого соціального розвитку. Яків - учений і пастух, що «жив у наметах», витісняє простакуватого Ісава - звіролова й кочівника, «степовика». Обидва брати зображені як символічні образи мисливця i осілого скотаря з різними характерами, які відповідали їхньому способу життя. Вони ведуть непримиренну боротьбу, ще перебуваючи у лоні матері, $\mathrm{i}$ це надзвичайно тривожить Ревеку, але сам Яхве тлумачить їй, що різні народи підуть від їі синів (Бут. 25, 23). Головний конфлікт оповіді суперечка близнюків про спадок і благословення їхнього батька Ісаака. Поведінка Якова, який уперто добивається для себе прихильності спочатку у батька, а пізніше - борючись із Богом за отримання цього благословення, видається дещо дивною. Однак тим і цінний Яків для Бога, що послідовно бореться за цю прихильність. I тут важлива деталь: сам Бог дає пророцтво для їхньої матері Ревеки про вибраність молодшого сина і його перевагах над старшим. Реакція Ісава на обман Якова передбачувана: «Та й зненавидів Ісав Якова за благословення, що ним благословив його батько. I сказав собі Ісав у серці: «Прийдуть дні плачу по моєму батькові, тоді уб’ю Якова, брата свого» (Бут. 27, 41). Така реакція ясно свідчить, що Ісав не себе звинуватив за зраду (продаж первородства), а Якова, продемонструвавши ще раз, що він $\epsilon$ представником плотського способу мислення.

Цей біблійний прецедент, коли первісток за правом народження замінений на первістка за сильним прагненням стати таким за духом, проходить червоною ниткою через увесь ТаНаХ, врешті окресливши пріоритет для Бога - первістком є не той, хто першим народився, але той, хто $\epsilon$ таким за духом [7]. Ставлення Бога до обману Якова в тексті не означене, єдине, що відомо - це те, що отримати благословення від батька Якову було недостатньо. Він виборов це благословення ще й у самого Бога в нелегкому герці (Бут. 32, 26). Ще одним свідченням нехтування Ісавом ідеями Завіту $є$ те, що він одружився на дочках Ханаану, не прийнятних для Бога (Бут. 24, 3). Яків же повинен був одружитися правильно, тому його втеча до землі Лавана (до родичів Ревеки) формально була обставлена як намір сватання, на що Ісаак змушений був погодитися, фактично благословивши Якова на втечу, щоб запобігти братовбивству. По дорозі Яків отримує від Яхве обіцянку повернути його в дім батька. Опинившись на чужині, Яків близько двадцяти років опирається прагненню повернутися додому, але врешті туга за рідною землею пересилює страх перед ненавистю з боку Ісава і підштовхує Якова на 
рішучий крок. Все подальше життя Якова - череда гірких i важких випробувань і спокут; текст акцентує на тому, що отримане неправедним шляхом (хоча й належне тобі) тягне за собою неминучу відплату. За цей час Ісав, не дивлячись на те, що втратив право первородства, надбав багатств $\mathrm{i}$ влади, і зустрів свого брата 3 військами. Але як тільки він побачив свого брата, його охопила радість. «...ІІав прибіг йому назустріч, обійняв його i припав йому на шию та й поцілував його, і плакали обидва» (Бут. 33, 4). Текст презентує перший крок до більш мирних взаємостосунків між братами, ніж ті, що їх виявили Каїн і Авель. Однак до справжнього примирення в темі «брат проти брата» ще далеко. ТаНаХ подає історію стосунків двох народів едомолян i ізраїльтян, родоначальниками яких стали Ісав i Яків, як непримиренну ворожнечу.

Ісав будує місто Едом (сучасна Петра в Йорданіiі), статтями прибутку якого були розбійницькі напади на сусідні держави, захоплення рабів і подальша работоргівля, грабунок купецьких караванів, які шукали притулку в Едомі (місто знаходилося на перетині головних торгівельних шляхів). Держава не мала власного виробництва і жила за рахунок піратства. Релігія Едомського царства була найбільш кривавою на Давньому Сході, оскільки кожного дня жерці-едомляни приносили богові Сонця криваві людські жертви. Біблійні пророки неодноразово зверталися до Едомського царства як до джерела зла, закликаючи покаятись (Ісая, 34; Єремія 49,10; Єзекиїл 25, 13; Амос 9,12; Авдій 1, 18), і передрікали загибель і знищення Едому, перетворення його в пустелю. I дійсно, після тисячі років панування роду Ісава пророцтва збулися, Петра стає мертвим містом. Царь Ірод Великий по своєму батькові Антипатру був едомлянином, нащадком Ісава. Ця фігура страшного царя, «останнього едомлянина», в якому втілились всі риси його народу, стала крапкою в існуванні усього племені. Біблійний Автор підкреслює, що навіть найвеличніші краї, де відсутній Бог - приречені на смерть.

ТаНаХ послідовно наголошує на принципових відмінностях едомлян i ізраїльтян, на перевазі роду Якова-Ізраїля над родом Ісава. Падіння останнього обумовлене домінантою плотських, миттєвих фізичних бажань. Ісаву хотілося їсти і він бажав отримати їжу за будь-яку ціну, сочевична юшка важливіша за первородство, головне - втамувати голод (аналогія 3 Свою, яка спокусилася плодом, не думаючи про наслідки). Будучи нащадком Авраама, Ісав знав, що божому народу заради збереження монотеїзму, заради захисту від деградації не можна було одружуватися з чужоземками. Однак він бере за жінок хананеянок, і після цього всі язичницькі культи цього народу стали головними серед нащадків Ісава, призвівши його до загибелі (одруження на чужоземній принцесі ледь не згубило самого царя Соломона). Віковічна заздрість едомлян до ізраїльтян, заздрість, яка зсередини з'їдає людину, зловтіха, самозвеличення і жадоба помсти врешті визначили долю народу Ісава, його занепад і самознищення. 
Ревниве протистояння між братами рефреном звучить протягом усієї Книги Буття і досягає апогею в більш складній фінальній історії - в оповіді про Йосифа і його братів - своєрідній варіації близнюкового міфу.

Усе починається зі знаменитого кольорового одягу - дарунку Якова своєму молодшому синові Йосифу, що стало символом того, що саме він буде нащадком батьківського спадку. I знову старші брати Йосифа переповнені ревнощами і злобою. Крім того, Йосиф страшенно дратує їх через свої сни і пророчі видіння. Втім, Йосиф давав підстави для недружелюбного ставлення з боку братів, оскільки «доносив своєму батькові лихі про них вістки» (Бут. 37, 2). Вони забрали Йосифів кольоровий плащ, зімітували нещасний випадок (напад хижого звіра) i продали молодшого брата работорговцям. Показово, що старші брати не наважилися вчинити реального братовбивства, пам'ятаючи наслідки історії Каїна i Авеля. Опинившись у Єгипті, Йосиф стає рабом знатного вельможі Потифара, але обмовлений його дружиною, потрапляє до тюрми. Від смерті Йосифа рятує його особливий дар тлумачення снів, завдяки якому юнака наближають до фараонового двору, а згодом, оцінивши його ділові і моральні якості, правитель призначає Йосифа на головну державну посаду в Єгипті. Йосиф отримує неймовірну владу i багатство i, врешті, у нього з'являється можливість помститися братам, що прибули до Єгипту, рятуючись від голоду. Йосиф розуміє, що може знищити їх, як Каїн знищив Авеля, але замість цього він тепло приймає їх: «... не завдавайте собі жалю і не ятріть себе, що продали мене сюди» (Бут. 45, 5). Перед тим, як відкритися братам (ті не впізнали його), Йосиф пересвідчується, що важким тягарем несуть вони в їхніх душах скоєний злочин (Бут. 42, 21). Торжеством прощення і любові завершується драматична історія Йосифа і його братів, ламаючи традиційну для близькосхідної традиції схему близнюкового міфу. Більше того, Йосиф навіть висловив братам думку, що продаж його у рабство був актом Божого провидіння з метою вирятувати дванадцять колін Ізраїлевих [1].

Текст про Йосифа є майже реалістичною повістю, в якій практично відсутне пряме втручання Яхве, оповідь носить відверто секулярний характер, однак вся вона просякнута ідеєю залежності людської історії від волевиявлення Провидіння. Безневинне страждання праведника за версією ТаНаХу завжди винагороджується і $є$ благом для його нащадків. Цим повість про Йосифа суттєво відрізняється від шумерсько-аккадських і єгипетських варіантів оповідей про безневинного страждальця, де невмотивована байдужість богів стосується як долі грішника, так і праведника, і ревне поклоніння останнього ніяким чином не винагороджується $[11 ; 16]$.

Давньосхідна традиція архаїчного близнюкового міфу, яка особливим чином акцентує світоглядні бінарності, в сакральних текстах віровчень аврамістичних релігій еволюціонувала від непримиримої ворожнечі братів до пошуків ними життєвих компромісів. При цьому акцентуація робиться на тому, що брат - персоніфікація фізичного, матеріального начала під впливом іншого брата, який втілює начало духовне, що походить від Бога, 
поступового стає на шлях усвідомлення руйнівної дії насилля, насамперед для самого джерела агресії.

\section{ЛIТЕРАТУРА}

1. Аверинцев С.С. Иосиф // Мифы народов мира. Т. 1 / С.С. Аверинцев М.: Советская энциклопедия, 1987. - С. 555-558.

2. Агада. Сказания, притчи, изречения Талмуда и мидрашей. - М.: Эксмо, 2006. - 528 с. - (Антология мудрости).

3. Вавилонский Талмуд: Антология Аггады - Тель-Авив, 2001. - 324 с.

4. Два брата // Сказки и повести Древнего Египта. - М.: Наука, 1979. С. 87-103.

5. Еврейская энциклопедия. Под ред. И. Орена. - Иерусалим, 1976-1992. T. 1-6.

6. Иванов В.В. Близнечные мифы // Мифы народов мира. Т. 1 / В. В. Иванов - М.: Советская энциклопедия, 1987. - С. 174-176.

7. Иванов В. В. Иаков // Мифы народов мира. Т. 1 / В.В. Иванов - М.: Советская энциклопедия, 1987. - С. 474-476.

8. Коран. Перевод смыслов и комментарии Имам В. Прохоровой. - М.: Рипол Классик, 2007. - 800 с.

9. Кочубей Б., Семенов В. Близнецы: проблемы воспитания и развития / Б. Кочубей - М., 1985. № 6. - С. 36-54.

10. Мишна. Трактат Авот. - Иерусалим, 1990. - 336 с.

11. Про безневинного страждальця / Пер. М. Луцюка // Синопсис: текст, контекст, медіа, 2014, № 3 (7) - Електронний ресурс - Режим доступу: http://synopsis.kubg.edu.ua/index.php/synopsis/article/view/99/87\#

12. Разговор («ОН сестре говорит ласково...» Спор между скотоводством и земледелием) / От начала начал. Антология шумерской поэзии. - СПб: Центр «Петербургское востоковедение», 1997. - С. 127-131.

13. Святе Письмо Старого та Нового Завіту / Пер. За ред. І. Хоменка - Рим: Verbo Divino, 1988.

14. Синило Г.В. Древние литературы Ближнего Востока и мир TAНАХА (Ветхого Завета) / Г.В. Синило - Минск: Экономпресс, 1998. $471 \mathrm{c}$.

15. Тернер В. Символ и ритуал. - М.: Наука, 1983. - 277 с.

16. Чиркави Саид Афанди. История пророков. Т. 1 / Саид Афанди Чиркави - Махачкала: Нуруль иршад, 2010. - 316 с.

17. Щедровицкий Д.В. Введение в Ветхий Завет. Пятикнижие Моисеево / Д.В. Щедровицкий - М.: Оклик, 2010. - 1088 с.

18. Штейнзальц А. Контуры Талмуда / А. Штейнзальц - Тель-Авив, 1981. -249 c.

19. Girard R. La violence et le sacré. / R. Girard - Paris: Bernard Grasset, 1972.

20. Girard R. Violence and Religion: Cause or Effect? / R. Girard Hedgehog Review, 2003, Vol. 6, № 1, P. 8-20. 
Статья посвящена развитию и трансформации близнечного мифа в древневосточной среде на примере древней мифологии средиземноморских культур (Древний Египет, Месопотамия, Палестина). Сюжет о братьяхблизнецах (жизненных антиподах) - непременная составляющая древневосточной литературной традици, и вместе с космогоническими и антропогоническими мифами является архетипическим. Анализируются древнееврейские варианты близнечного мифа, представленные в текстах Tоры (Пятикнижие Моисеево), прослеживается эволючия близнечной метафоры в ветхозаветных повествованиях о Каине и Авеле, Исаве и Иакове, Иосифе Прекрасном. Наблюдается освоение близнечных сюжетов традиџией Предания аврамистических вероучений.

Ключевые слова: Древний Восток, близнечный миф, ТаНаХ, Тора, Каин и Авель, Исав и Иаков, Иосиф Прекрасный.

This article is dedicated to development and transformation of myth about twins in Ancient Middle East ambiance through Ancient Mythology of Submediterranean cultures (Ancient Egypt, Mesopotamia, Palestine). The twinbrothers (lifelong antipodes) theme is a vital part of Ancient Middle East literary tradition. Together with cosmogonical and antropogonical myths they are archetypical. The Hebrew versions of twin-brothers myths which can be found in Torah (Pentateuch of Moses) have been analyzed. The evolution of twin metaphor is traced through Old Testament stories about Cain and Abel, Esau and Jacob, Joseph the Fair. Here the acquisition of plots about twin brothers in the tradition of Abrahamic religions can be observed.

Keywords: Ancient Middle East, twin myth, TaNaK, Torah, Cain and Abel, Esau and Jacob, Joseph the Fair. 